\title{
$\beta_{2}$ glikoproteina-I - podstawowy antygen w zespole antyfosfolipidowym
}

\author{
$\beta_{2}$ glycoprotein-I - the main antigen in antiphospholipid syndrome
}

\author{
Jacek Musiał \\ II Katedra Chorób Wewnętrznych, Collegium Medicum Uniwersytetu Jagiellońskiego, Kraków
}

Streszczenie: Pojęcie „przeciwciała antyfosfolipidowe” opisujace charakterystyczną cechę laboratoryjną zespołu antyfosfolipidowego (antiphospholipid syndrome - APS) jest mylące. Sugeruje bowiem, iż autoprzeciwciała te skierowane są przeciwko fosfolipidom. Tymczasem swoistym antygenem są białka wykazujące powinowactwo do fosfolipidów. W APS przeciwciała odgrywające najpewniej rolę patogenetyczną i najsilniej związane z objawami klinicznymi skierowane są przeciwko białku surowicy - $\beta_{2}$ glikoproteinie-I. Przedyskutowano prawdopodobny mechanizm działania przeciwciał skierowanych przeciwko $\beta_{2}$ glikoproteinie-I.

Słowa kluczowe: $\beta_{2}$ glikoproteina-I, przeciwciała przeciwko $\beta_{2}$ glikoproteinie-I, zespół antyfosfolipidowy

Abstract: The term "antiphospholipid antibodies" describing a laboratory hallmark of antiphospholipid syndrome (APS) is a misnomer. It suggests that antibodies are directed against phospholipids. Meanwhile the specific antigens are in fact proteins demonstrating an affinity to phospholipids. In APS antibodies directed against a serum protein, $\beta_{2}$ glycoprotein-I, play most probably a pathogenic role and are strongly associated with clinical symptoms of the syndrome. Putative mechanisms of action of anti- $\beta_{2}$ glycoprotein-I antibodies are discussed.

Key words: $\beta_{2}$ glycoprotein-I, anti- $\beta_{2}$ glycoprotein-I antibodies, antiphospholipid syndrome

Kiedy przed 20 laty tworzono pojęcie zespołu antyfosfolipidowego (antiphospholipid syndrome - APS) [1], posługiwano się do dziś stosowanym określeniem „przeciwciała antyfosfolipidowe", sugerując, iż autoprzeciwciała występujące w tym zespole skierowane są przeciwko fosfolipidom, głównie, jak już wówczas wiedziano, ujemnie naładowanym strukturalnym fosfolipidom błony komórkowej. Do wykrywania tych przeciwciał (poza metodami koagulometrycznymi - wykrywanie antykoagulantu toczniowego) jako antygen powszechnie stosowano kardiolipinę. W błonie komórkowej u ludzi fosfolipid ten jednak nie występuje. Stąd niektórzy preferowali testy immunoenzymatyczne (ELISA) z użyciem innych, obecnych u ludzi fosfolipidów, głównie fosfatydyloseryny.

Kilka lat później, w 1990 roku, 3 grupy badawcze - z Europy, Japonii i Australii - jednocześnie doniosły, iż dla wiązania się przeciwciał $z$ ujemnie naładowanymi fosfolipidami niezbędne jest białko surowicy $-\beta_{2}$ glikoproteina-I ( $\beta_{2}$ GPI) [2]. To do niej w rzeczywistości wiążą się tak zwane przeciwciała

Adres do korespondencji:

prof. dr hab. med. Jacek Musiał, II Katedra Chorób Wewnętrznych, Collegium Medicum Uniwersytetu Jagiellońskiego, ul. Skawińska 8, 31-066 Kraków, tel./fax: 012-430-53-14,e-mail: mmmusia@cyf-kr.edu.pl

Pol Arch Med Wewn. 2007; 117 (Suppl): 59-60

Copyright by Medycyna Praktyczna, Kraków 2007 antyfosfolipodowe (antiphospholipid antibodies - aPL). Później okazało się, że i inne białka mogą pośredniczyć w tych reakcjach. Najczęściej w APS wykrywano przeciwciała przeciwprotrombinowe. Wydają się one jednak nie odgrywać istotniejszej roli patogenetycznej w powstawaniu typowych klinicznych objawów zespołu [3]. Przeciwciała przeciwko innym białkom występują w APS bardzo rzadko i nie wiążą z występowaniem objawów klinicznych.

$\beta_{2}$ glikoproteina-I to białko syntetyzowane $\mathrm{w}$ wątrobie i obecne w surowicy w stężeniu $50-300 \mu \mathrm{g} / \mathrm{ml}(0,25-5,0 \mu \mathrm{M})$. $\beta_{2}$ GPI zbudowana jest $z$ jednego lańcucha polipeptydowego zawierającego 326 aminokwasów oraz glikanów wiążących się do tego łańcucha i stanowiących ok. 20\% masy cząsteczki (m.cz. $36,3 \mathrm{kDa}$ ). Fizjologiczna rola $\beta_{2}$ GPI nie jest znana. Opisywano wrodzony całkowity brak tego białka u ludzi - bez jakichkolwiek następstw klinicznych [4]. Łańcuch polipeptydowy $\beta_{2}$ GPI zbudowany jest z pięciu domen. Domena $V$, posiadająca miejsce o dodatnim ładunku, odpowiada za silne wiązanie się białka do ujemnie naładowanych fosfolipidów błony komórkowej. Natomiast aPL wiążą się głównie do domeny I [5,6].

W ostatnich latach wykazano bardzo ścisły związek pomiędzy przeciwciałami zależnymi od $\beta_{2}$ GPI a klinicznymi objawami APS, przede wszystkim zakrzepicą. Dotyczy to tak przeciwciał o własnościach antykoagulantu toczniowego [7], 


\section{ARTYKUŁY POGLĄDOWE}

jak i tych wykrywanych metodami immunoenzymatycznymi z użyciem kardiolipiny [8]. Stąd zależność aPL od $\beta_{2}$ GPI stała się wymogiem, uwzględnionym w ostatnio zmodyfikowanych kryteriach klasyfikacyjnych zespołu [9]. Badania de Groota z Utrechtu [8] i Arnouta z Lowanium [10] dowiodły, iż cząsteczki $\beta_{2}$ GPI silnie związane z ujemnie naładowanymi fosfolipidami błony komórkowej posiadają własność wiązania patogennych przeciwciał występujących w APS i ulegają pod ich wpływem dimeryzacji (jedna cząsteczka przeciwciała wiąże się jednocześnie z dwoma unieruchomionymi cząsteczkami $\beta_{2}$ GPI). Przy czym wymóg jednoczesnego udziału ujemnie naładowanych fosfolipidów i $\beta_{2}$ GPI wynika z faktu, że patogenne przeciwciała wiążą się nie do $\beta_{2}$ GPI w fazie płynnej, lecz do białka, które uległo zmianom konformacyjnym pod wpływem wiązania z fosfolipidami [5]. Taki kompleks przeciwciała $z$ dimerem $\beta_{2}$ GPI aktywuje prawdopodobnie komórkę (np. płytkę krwi czy monocyt) na drodze receptorowej [8,11], wiodąc do ujawnienia fenotypu prozakrzepowego. Istnieją też inne próby wyjaśnienia patogennego wpływu przeciwciał anty- $\beta_{2}$ GPI na naczynia krwionośne. Bierze się pod uwagę stres oksydacyjny i zaburzoną osłonę antyoksydacyjną. W tej koncepcji podstawową rolę miałyby odgrywać kompleksy przeciwciał przeciwko $\beta_{2}$ GPI (anty- $\beta_{2}$ GPI) z oksydowanymi lipoproteinami [12].

Uznanie $\beta_{2}$ GPI za podstawowy antygen dla patogennych przeciwciał APS spowodowało opracowanie metod immunoenzymatycznych dla bezpośredniego wykrywania takich przeciwciał i włączenie ich do kryteriów klasyfikacyjnych zespołu [8]. Okazało się, że przeciwciała takie rzeczywiście współwystępują z objawami APS ze znaczną swoistością, jednak ich czułość jest niewielka [13]. Nie mogą zatem całkowicie zastąpić klasycznych oznaczeń wykonywanych w obecności fosfolipidów (np. kardiolipiny). Natomiast ich współwystępowanie $\mathrm{z}$ innymi aPL i utrzymywanie się wysokich poziomów w dłuższym przedziale czasu jest charakterystyczne dla wielu chorych z powikłaniami zakrzepowymi i kobiet z powikłaniami położniczymi $[14,15]$.

Można zadać pytanie - dlaczego w APS te klasyczne oznaczenia przeciwciał antykardiolipinowych wypadają dodatnio częściej (większa czułość) niż oznaczenia przeciwciał anty- $\beta_{2}$ GPI. Wynika to zapewne $z$ techniki laboratoryjnej oznaczeń, w której kardiolipina jako fosfolipid opłaszcza plastikową płytkę, tworząc ujemnie naładowaną powierzchnię fosfolipidową. Wiązanie się do niej $\beta_{2}$ GPI (będącej w nadmiarze w każdej badanej surowicy) przypomina prawdopodobnie zjawiska zachodzące in vivo, łącznie z właściwą zmianą konformacyjną białka, niezbędną do związania się z nim przeciwciała.

Podejrzewano, że większa skłonność do tworzenia anty- $\beta_{2}$ GPI może mieć podłoże genetyczne i wiązać się z polimorfizmem genu kodującego $\beta_{2}$ GPI. Następstwem takiego polimorfizmu jest substytucja Val/Leu247 w łańcuchu polipeptydowym [16]. Badania te prowadzone były w małych grupach chorych japońskich i w grupach mieszanych etnicznie. Jednak w białej populacji europejskiej zależności takich nie potwierdzono [17].

W chwili obecnej przyjmujemy, iż pośród heterogennej grupy autoprzeciwcial antyfosfolipidowych obecnych w APS patogenne przeciwciała to te, które w rzeczywistości skierowane są przeciwko białku, $\beta_{2}$ GPI związanej z ujemnie naładowanymi fosfolipidami błony komórkowej. Pomimo wielu starań nie udało się do chwili obecnej opracować ogólnie uznanych metod wykrywania takich przeciwciał, które jednocześnie wykazywałyby zależność od $\beta_{2}$ GPI i charakteryzowały się nie tylko wysoką swoistością, ale i czułością w stosunku do typowych objawów APS. Można sobie jednak zadać pytanie, czy taki test w ogóle istnieje. Nie da się przecież wykluczyć, iż pośród aPL związek z objawami klinicznymi wykazywać mogą jeszcze inne, dotąd nie zidentyfikowane przeciwciała.

W międzyczasie w mocy pozostają propozycje zawarte w zmodyfikowanych kryteriach klasyfikacyjnych APS [9], nakazujące w postępowaniu diagnostycznym oznaczenia tak w kierunku antykoagulantu toczniowego, jak i przeciwciał antykardiolipinowych i anty- $\beta_{2}$ GPI.

\section{PIŚMIENNICTWO}

1. Harris EN. Syndrome of the black swan. Br J Rheumatol. 1987; 26: 324-326.

2. de Groot PG, Bouma B, Lutters BCH, Derksen RHWM. $\beta_{2}$-glycoprotein-I and anti$-\beta_{2}$-glycoprotein-I antibodies. In: Asherson RA, Cerevera R, Piette J-C, Shoenfeld $Y$ eds. The Antiphospholipid Syndrome II. Autoimmune thrombosis. Amsterdam, Elsevier, 2002: 45-57.

3. Galli M, Barbui T. Antiprothrombin antibodies: Detection and clinical significance in the antiphospholipid syndrome. Blood. 1999; 93: 2149-2157.

4. Takeuchi $R$, Atsumi $T$, leko $M$, et al. Coagulation and fibrinolytic in 2 siblings with 32-glycoprotein I deficiency. Blood. 2000; 96: 1594-1595.

5. de Laat B, Derksen RHWM, van Lummel M, et al. Pathogenic anti- $\beta 2$-glycoprotein I antibodies recognize domain I of $\beta 2$-glycoprotein I only after a conformational change. Blood. 2006; 107: 1916-1924.

6. Ioannou Y, Pericleous C, Giles I, et al. Binding of antiphospholipid antibodies to discontinuous epitopes on domain I of human $\beta_{2}$-glycoprotein I. Arthritis Rheum. 2007; 56: $280-290$.

7. de Laat HB, Derksen RH, Urbanus RT, et al. $\beta 2$-glycoprotein I-dependent lupus anticoagulant highly correlates with thrombosis in the antiphospholipid syndrome. Blood. 2004; 104: 3598-3602.

8. de Groot PG, Derksen RHWM. Pathophysiology of the antiphospholipid syndrome. J Thromb Haemost. 2005; 3: 1854-1860.

9. Miyakis S, Lockshin MD, Atsumi T, et al. International consensus statement on an update of the classification criteria for definite antiphospholipid syndrome (APS). J Thromb Haemost. 2006; 4: 295-306.

10. Arnout J, Jankowski M. Antiphospholipid antibodies: prothrombotic mechanisms and laboratory diagnosis. In: Arnout J, de Gaetano G, Hoylaerts M, Peerlinck K, Van Geet C, Verhaeghe R, eds. Thrombosis. Fundamental and clinical aspect. Leuven, University Press, 2003: 371-392.

11. Lutters BC, Derksen RHWM, Tekelenburg WL, et al. Dimers of $\beta 2$-glycoprotein I increase platelet deposition to collagen via interaction with phospholipids and the apolipoprotein E receptor 2'. J Biol Chem. 2003; 278: 33831-33838.

12. Ames PRJ, Alves JD, Lopez LR, et al. Antibodies against $\beta 2$-glycoprotein I complexed with an oxidised lipoprototein relate to intima thickening of carotid arteries in primary antiphospholipid syndrome. Clin Develop Immunol. 2006; 13: 1-9.

13. Musial J., Swadzba J, Motyl A, Iwaniec T. Clinical significance of antiphospholipid protein antibodies. Receiver Operating Characteristics plot analysis. J Rheumatol. 2003; 30: 723-730.

14. Sailer T, Zoghlami C, Kurz C, et al. Anti- $\beta 2$-glycoprotein I antibodies are associated with pregnancy loss in women with the lupus anticoagulant. Thromb Haemost. 2006; 95: 796-801.

15. Danowski A, Kickler TS, Petri M. Anti-beta2-glycoprotein I: prevalence, clinical correlations, and importance of persistent positivity in patients with antiphospholipid syndrome and systemic lupus ereythematosus. J Rheumatol. 2006; 33: 1775-1779.

16. Yasuda S, Atsumi T, Matsuura E, et al. Significance of valine/leucine247 polymorphism of $\beta_{2}$-glycoprotein I in antiphospholipid syndrome. Arthritis Rheum. 2005; 52: 212-218.

17. Swadzba J, Sanak M, Iwaniec T, et al. Valine/Leucine247 polymorphism of $\beta_{2}$-glycoprotein I in patients with antiphospholipid syndrome: lack of association with anti- $\beta_{2}$-glycoprotein I antibodies. Lupus. 2006; 15: 218-222. 